\title{
PENGEMBANGAN PENDIDIKAN BERBUDAYA NIRKEKERASAN DI MADRASAH IBTIDAIYAH SE-KABUPATEN JEMBER
}

\section{Nino Indrianto*1, Zainuddin Al-Haj Zaini*2, Nina Hayuningtyas*3}

PGMI, Fakultas Tarbiyah dan Ilmu Keguruan (FTIK) IAIN Jember, Indonesia ${ }^{1}$ ninoindrianto@gmail.com, ${ }^{2}$ zainuddinzaini20@gmail.com, 3 nina.hayuningtyas99@gmail.com

\begin{abstract}
The number of violence in the education environment is still a problem for education in Indonesia. Madrasah as part of the national education system should be able to provide solutions to these problems. The development of nonviolent culture education is expected to be able to provide solutions, so that produces some graduates who have selfcontrol, noble character and have a sense of togetherness as one nation and country. This research aimed to determine prevention and control efforts and also the sanctions against perpetrators of violence in realizing a non-violence culture at MIN 1 and MIN 6 Jember. This type of research was qualitative research with sampling techniques using purposive sampling. Furthemore, the methods used to collect data were documentation, interview, and observation. The results of this research indicated that: 1) MIN 1 Jember undertook preventive measures by making activities that can build communication among the members of madrasah, while MIN 6 Jember took preventive action efforts by making activities that can build closeness among the members of madrasah, 2) MIN 1 and MIN 6 Jember ,in efforts to deal with violence, followed up the violence cases propotionally, 3) MIN 1 and MIN 6 Jember gave the sanctions or punishments to the perpetrators of violence verbally, writtenly, and other educational sanctions.
\end{abstract}


Keywords: Educational Development, Non-violent Culture, Islamic Elementary School

\begin{abstract}
Abstrak
Banyaknya tindak kekerasan di lingkungan satuan pendidikan masih menjadi problem bagi dunia pendidikan di Indonesia. Madrasah sebagai bagian dari sistem pendidikan nasional harus mampu memberi solusi terhadap masalah tersebut. Pengembangan pendidikan berbudaya nirkekerasan diharapkan mampu memberi solusi, agar memunculkan lulusan yang memiliki pengendalian diri, akhlak mulia, serta memiliki rasa kebersamaan sebagai satu bangsa dan negara. Penelitian ini bertujuan untuk mengetahui upaya pencegahan dan penanggulangan serta sanksi terhadap pelaku tindak kekerasan dalam mewujudkan budaya nirkekerasan di MIN 1 dan MIN 6 Jember. Jenis penelitian ini adalah penelitian kualitatif dengan teknik pengambilan sampel menggunakan purposive sampling. Metode pengumpulan data melalui dokumentasi, wawancara, dan observasi. Hasil penelitian ini menunjukkan bahwa: 1) MIN 1 Jember melakukan upaya tindakan pencegahan dengan membuat kegiatan-kegiatan yang dapat membangun komunikasi antar warga madrasah sedangkan MIN 6 Jember melakukan upaya tindakan pencegahan dengan membuat kegiatan-kegiatan yang dapat membangun kedekatan antar warga madrasah, 2) MIN 1 dan MIN 6 Jember dalam upaya penanggulangan tindak kekerasan dengan menindaklanjuti kasus kekerasan yang terjadi secara proporsional, 3) MIN 1 dan MIN 6 Jember memberikan sanksi terhadap pelaku tindak kekerasan berupa teguran lisan, tulisan, serta sanksi lainnya yang bersifat mendidik.
\end{abstract}

Kata Kunci: Pengembangan Pendidikan , Budaya Nirkekerasan, Madrasah Ibtidaiyah 
AL-MUDARRIS:journal of education, Vol. 2. No. 1 April 2019, ISSN: 2620-5831 (print), ISSN: 2620-4355(online)

DOI:

\section{A. PENDAHULUAN}

Perkembangan teknologi telah menjadi sumber informasi yang banyak mempertotonkan budaya kekerasan yang menjadi sumber inspirasi bagi anak-anak.Tontonan televisi, film, koran, majalah hingga fiksi-fiksi dengan tokoh-tokoh banyak mempertunjukkan aksi kekerasan. Dengan dipertontonkannya berbagai bentuk kekerasan, anak-anak beranggapan bahwa setiap konflik dapat diselesaikan dengan aksi kekerasan seperti perkelahian. Aksi Perkelahian kadang dianggap sebagai sesuatu yang normal dan dapat dibenarkan.

Sekolah/madrasah adalah bagian dari sistem pendidikan nasional yang memiliki peranan penting untuk menjadikan peserta didik yang mempunyai tanggung jawab untuk menjaga keamanan bangsa. Hal ini sesuai dengan fungsi dari pendidikan nasional yang tertuang dalam Undang-undang Sistem Pendidikan Nasional No. 20 Tahun 2003 pada Pasal 3 yakni untuk membentuk watak dan peradaban bangsa yang bermartabat untuk mencerdaskan kehidupan bangsa, yang bertujuan untuk meningkatkan potensi peserta didik agar menjadi manusia yang beriman dan bertakwa kepada Tuhan Yang Maha Esa, berakhlak mulia, berilmu, kreatif, sehingga mampu menjadi warga negara yang demokratis serta bertanggung jawab.

Disamping itu, pasal 28J ayat 1 dan 2 menjelaskan bahwa penghormatan terhadap hak asasi manusia dalam kehidupan berbangsa dan bernegara adalah merupakan suatu kewajiban bagi tiap individu. Sedangkan pelaksanaan hak dan kebebasan itu sendiri dibatasi oleh undang-undang.

Dalam hal ini, penyebaran nilai-nilai pluralisme, multikulturalisme, inklusivisme dan toleransi adalah merupakan salah satu tanggung jawab sekolah dan madrasah selaku lembaga pendidikan. Namun, pada kenyataannya pendidikan yang diajarkan di sekolah, madrasah, pesantren, kampus serta institusi Islam lainnya belum mampu memberikan kontribusi nyata dalam memberantas aksi "premanisme". Bahkan seringkali melahirkan lulusan-lulusan yang "tempramen" yang hal ini 
dibuktikan masih banyaknya tawuran antar pelajar dan aksiaksi kriminal yang melibatkan pelajar.

Sekolah dan madrasah yang seharusnya menyelenggarakan pendidikan yang aman, nyaman, dan menyenangkan kenyataanya masih didapati sejumlah kasus yang menujukkan adanya tidak kekerasan di lingkungan sekolah/madarasah. Berdasar data yang ada terdapat sebanyak 84\% siswa pernah mengalami kekerasan di sekolah, $45 \%$ siswa laki-laki dan $22 \%$ siswa perempuan menyebutkan bahwa pelaku kekerasan dilakukan oleh oknum guru atau oknum petugas sekolah, sedangkan terdapat $40 \%$ siswa usia 13-15 tahun melaporkan pernah mengalami kekerasan fisik oleh teman sebaya, $75 \%$ siswa mengakui pernah melakukan kekerasan di sekolah, dan 50\% anak melaporkan mengalami perundungan (bullying) di sekolah.

Untuk mengatasi tindak kekerasaan terutama di lingkungan sekolah/madrasah, pemerintah mengeluarkan regulasi melalui Permendikbud Nomor 82 Tahun 2015 tentang Pencegahan dan Penanggulangan Tindak Kekerasan di Lingkungan Satuan Pendidikan. Regulasi tersebut merupakan acuan dalam mengembangkan sistem pendidikan di sekolah dan madrasah untuk mewujudkan pendidikan nirkekerasan. Salah satu sistem pendidikan yang perlu dikembangkan adalah pendidikan berbudaya nirkekerasan. Pengembangan pendidikan berbudaya nirkekerasan diharapkan mampu memberi solusi, sehingga akan semakin banyak lulusan yang memiliki pengendalian diri, akhlak mulia, serta memiliki rasa kebersamaan sebagai satu bangsa dan negara.

Oleh sebab itu pendidikan berbudaya nirkekerasan sangatlah penting untuk dikembangkan terutama bagi siswa sekolah dasar atau madrasah ibtidaiyah. Pendidikan berbudaya nirkekerasan di sekolah dan madrasah sangat penting untuk mencetak generasi yang tidak sempit dalam berfikir, berperilaku, dan memandang realitas keberagaman

1 Medcom.id, 'KPAI : 84 \% Siswa Pernah Alami Kekerasan Di Sekolah', Www.Medcom.Id, 2018. 
AL-MUDARRIS:journal of education, Vol. 2. No. 1 April 2019, ISSN: 2620-5831 (print), ISSN: 2620-4355(online)

DOI:

(kemajemukan). Pendidikan berbudaya nirkekerasan dapat memacu siwa untuk bisa menerima dan menyadari bahwa Indonesia merupakan negara yang memiliki berbagai ras, suku, adat istiadat dan agama yang berbeda-beda, dan supaya siswa dapat tulus menghargai perbedaan, serta tidak mengandalkan dan gemar menggunakan jalan kekerasan untuk mencapai tujuan pribadi atau golongan.

MIN 1 dan MIN 6 Jember dipilih sebagai lokasi penelitian dikarena keduanya telah mengimplemantasikan Permendikbud No.82 tahun 2015 dan dinilai berhasil. Keberhasilan ini dilihat dari tidak adanya tindak kekerasan diluar kewajaran yang terjadi MIN 1 maupun di MIN 6 Jember sejak tiga tahun terakhir.

Berdasarkan konteks penelitian tersebut, maka penelitian ini difokuskan pada bagaimana upaya pencegahan dan penanggulangan tindak kekerasan serta sanksi terhadap pelaku tindak kekerasan dalam mewujudkan budaya nirkekerasan di MIN 1 dan MIN 6 Jember? Adapun tujuan dari penelitian ini adalah untuk mengetahui upaya pencegahan tindak kekerasan dan penanggulangan serta sanksi yang diberikan kepada pelaku tindak kekerasan dalam mewujudkan budaya nirkekerasan di Madrasah Ibtidaiyah Negeri 6 Jember.

\section{B. KAJIAN PUSTAKA}

\section{Budaya Nirkekerasan}

Dalam Kamus Besar Bahasa Indonesia (KBBI) istilah budaya diartikan sebagai pikiran, adat istiadat, sesuatu yang sudah berkembang, sesuatu yang menjadi kebiasaan yang sukar diubah. ${ }^{2}$ Sedangkan istilah nirkekerasan berasal dari kata dasar "keras," yang kemudian diimbuhi dan dikembangkan menjadi kata "kekerasan". Sedangkan kata "kekerasan" punya tiga arti, yang pertama perihal atau sesuatu yang bersifat keras. Kedua, perbuatan seseorang atau sekelompok orang yang berakibat kecederaan atau

2 Departemen Pendidikan dan Kebudayaan, Pendidikan dan Kebudayaan, Kamus Besar Bahasa Indonesia (Jakarta: Balai Pustaka, 1997). 149. 
AL-MUDARRIS:journal of education, Vol. 2. No. 1 April 2019, ISSN: 2620-5831 (print), ISSN: 2620-4355(online)

DOI: 10.32478/al-mudarris.v2i1.223

kematian serta kerusakan fisik atau barang milik orang lain, ketiga, paksaan. ${ }^{3}$ Dengan demikian, dalam lingkup subjek, objek, tujuan, dan wilayahnya maka kekerasan bisa terjadi oleh siapa saja dan di mana saja.

Tindak kekerasan yang dimaksud dalam Permendikbud Nomor 82 Tahun 2015 Pasal 1 adalah merupakan perilaku yang dilakukan secara fisik, psikis, seksual, dalam jaringan (daring), atau melalui buku ajar yang mencerminkan tindakan agresif dan penyerangan yang terjadi di lingkungan satuan pendidikan dan mengakibatkan ketakutan, trauma, kerusakan barang, luka/cedera, cacat, dan atau kematian. ${ }^{4}$ Lebih detail, dalam permendikbud No.82 tahun 2015 Pasal 6 dijelaskan bentuk-bentuk tindak kekerasan di lingkungan satuan pendidikan antara lain: pelecehan, perundungan, penganiayaan, perkelahian, perpeloncoan, pemerasan, pencabulan, dan pemerkosaan. ${ }^{5}$

Lebih lanjut lagi, menurut Simon Fisher, istilah tindak kekerasan adalah tindakan, perkataan, sikap, berbagai struktur atau sistem yang menyebabkan kerusakan secara fisik, sosial atau lingkungan dan/atau menghalangi seseorang untuk meraih potensinya secara penuh. Saat ini, kekerasan diidentikan dalam wacana sehari-hari hampir sama dengan perkelahian atau bentrokan fisik. Padahal, menurut Simon Fisher kekerasan tidak hanya perkelahian atau bentrokan fisik, akan tetapi perkataan, tindakan, dan sikap manusia pun dapat dikategorikan sebagai aksi kekerasan. Contoh dari pernyataan ini adalah perkataan atau sikap; menghardik, mengancam, teror, atau memunculkan simbol-simbol tertentu pada saat tertentu. ${ }^{6}$

Sedangkan Nimer menuturkan bahwa nirkekerasan merupakan kombinasi antara sikap, pandangan, dan aksi yang dimaksudkan untuk mengajak orang di pihak lain

${ }^{3} \mathrm{http}: / / \mathrm{kbbi}$-offline.googlecode.com.

4 Permendikbud Nomor 82 Tahun 2015 Tentang Pencegahan dan Penanggulangan Tindak Kekerasan di Lingkungan Satuan Pendidikan.

${ }^{5}$ Ibid.

${ }^{6}$ Yohanes Suppriyadi, 'Pendidikan Anti Kekerasan; Paradigma Baru Dunia Pendidikan Menuju Kehidupan yang Harmonis di Masa Depan', Yohanessupriyadi.Blogspot.co.id, 2008. 
AL-MUDARRIS:journal of education, Vol. 2. No. 1 April 2019, ISSN: 2620-5831 (print), ISSN: 2620-4355(online)

DOI:

secara damai untuk mengubah pendapat, pandangan, dan aksi mereka dengan capaian kedamaian pula. Oleh karena itu, dalam gerakan nirkekerasan para pelakunya tidak pernah membalas (merespon) tindakan dari pihak lain dengan melakukan kekerasan. Sebaliknya, mereka justru berupaya untuk menyampaikan pesan ketabahan yang tegas dan desakan untuk mengatasi ketidakadilan dengan cara meminimalkan kemarahan dan kerusakan secara holistik. ${ }^{7}$

Jadi budaya nirkekerasan dalam konteks pendidikan berarti suatu sistem pendidikan yang proses dan tujuannya mengacu pada prinsip-prinsip kedamaian, tanpa adanya kekerasan atau paksaan yang bisa menimbulkan kematian dan kerusakan fisik maupun psikis orang lain. Disinilah fungsi sekolah yaitu sebagai lembaga yang berfungsi mentransmisikan budaya. ${ }^{8}$ Pengembangan Budaya positif disekolah menjadi hal penting yang harus diperhatikan karena kepribadian atau karakter seorang anak akan tumbuh berkembang sebagai produk kebudayaan. ${ }^{9}$ Internalisasi budaya nirkkekerasan kepada peserta didik merupakan upaya agar tercipta kondisi proses pembelajaran yang nyaman, aman dan menyenangkan.

\section{Nilai-nilai Pendidikan Berbudaya Nirkekerasan}

Dalam konsepsi pendidikan nirkekerasan, penekanan pendidikan tidak lagi ditujukan hanya terhadap kelompok etnik, agama dan kultural domain atau mainstream. Pendidikan nirkekerasan merupakan sikap peduli dan mau mengerti (difference), atau "politics of recognition" politik yang mengakui keberadaan orangorang dari berbagai kelompok yang ada di lingkungan sekitar mereka. ${ }^{10}$ Budaya nirkekerasan sejatinya diwariskan secara turun temurun kepada generasi muda melalui

${ }^{7}$ Mohammed Abu-Nimer, Nirkekerasan dan Bina Damai dalam Islam: Teori dan Praktik (Jakarta: Pustaka Alvabet, 2010).

8 Abdul Latif, Pendidikan Berbasis Nilai Kemasyarakatan (Bandung: Refika Aditama, 2005). 30.

${ }^{9}$ Nur Iman Subono, Erich Fromm: Psikologi Sosial Materialis yang Humanis (Jakarta: Kepik Ungu, 2010). 15.

${ }^{10}$ Suppriyadi. 
AL-MUDARRIS:journal of education, Vol. 2. No. 1 April 2019, ISSN: 2620-5831 (print), ISSN: 2620-4355(online)

DOI: 10.32478/al-mudarris.v2i1.223

internalisasi kebiasaan yang memfokuskan pada kemampuan untuk menilai mana yang benar dan mana yang salah secara tegas. Oleh karena itu, peserta didik perlu dikenalkan dan diajarkan tentang nilai-nilai kebaikan dan nilai-nilai keburukan pada diri mereka dan memberikan hukuman atau sanksi secara langsung maupun tidak langsung apabila terjadi pelanggaran. ${ }^{11}$

Unesco sebagai salah satu lembaga PBB yang bertujuan mewujudkan perdamain dunia melalui kegiatan pendidikan, merumuskan budaya damai (culture of peace) menjadi seperangkat nilai dan sikap yang didasarkan beberapa aspek sebagai berikut: 1) Penghargaan terhadap kehidupan (Respect All Life), 2) Menolak kekerasan (Reject Violence), 3) Berbagi dengan yang lain (Share with Others), 4) Mendengar untuk memahami (Listen to Understand), 5) Menjaga Kelestarian bumi (Preserve the Planet), 6) Solidaritas (Rediscover Solidarity), 7) Persamaan antara laki-laki dan perempuan, dan 8) Demokrasi (Democracy). ${ }^{12}$

Dari standar budaya nirkekrasan di atas, dapat disimpulkan bahwa penciptaan budaya nirkekerasan harus memuat nilai-nilai universal yang mampu menjamin kedamaian dan keamanan. Dalam melaksanakan pendidikan, praktik pembelajaran yang dilakukan harus bertumpu pada kepentingan peserta didik. Proses belajar diorientasikan sebagai upaya memanusiakan manusia yaitu siswa diakui, diterima dan dimanusiakan. ${ }^{13}$ Pada akhirnya, satuan pendidikan tidak hanya mewujudkan kedamaian pada lingkungan satuan pendidikan saja tetapi mampu mengaplikasikannya pada wilayah yang lebih luas yaitu terwujudnya perdamaian dunia.

11 A. Rifqi Amin, Pengembangan Pendidikan Agama Islam; Reinterpretasi Berbasis Interdisipliner (Yogyakarta: LkiS Pelangi Aksara, 2015).

${ }^{12}$ Wahyu Widhiarso M. Noor Rocman Hadjam, Damai Anti Kekerasan (Peace and Anti Violence) (Dirjen Pendidikan Menengah Umum, 2003). 14.

${ }^{13}$ Erich Fromm Paulo Fraire, Ivan Illich, Pendekatan Humanisme dan Pendidikan Pembebasan, terj. by Omi Intan Naomi (Yogyakarta: Pustaka pelajar, 1994). 434. 
AL-MUDARRIS:journal of education, Vol. 2. No. 1 April 2019, ISSN: 2620-5831 (print), ISSN: 2620-4355(online)

DOI:

\section{METODE PENELITIAN}

Penelitian ini merupakan jenis penelitian kualitatif yang menggunakan pendekatan filosofis, sosiologis dan psikologis. Teknik yang digunakan dalam penelitian ini adalah teknik purposive sampling dengan menggunakan metode dokumentasi, wawancara, dan observasi. Metode dalam menganalisis data menggunakan metode interpretasi, metode Induktif dan menarik kesimpulan serta verifikasi data menggunakan teknik triangulasi (triangulation) dan pengecekan kecukupan referensi (referential adequacy checks) dengan mengarsip data-data yang telah terkumpul selama penelitian di lapangan.

\section{HASIL DAN PEMBAHASAN}

1. Pengembangan Budaya Nirkekerasan di MIN 1 Jember

MIN 1 Jember dalam melakukan upaya tindakan pencegahan lebih mengedepankan komunikasi. Untuk itu kegiatan-kegiatan dibuat sebagai sarana komunikasi, seperti upacara, siraman rohani, rapat bulanan, paguyuban wali murid, dan pembentukan group whatsapp wali murid dan seleksi bagi siswa pindahan. ${ }^{14}$ MIN 1 Jember dalam menjamin keamanan sekolah dengan membangun pagar, adanya satpam, dan fasilitas antar jemput gratis bagi siswa yang rumahnya jauh. Sedangkan langkah prosedural yang dilakukan madrasah jika mendapati adanya dugaan/gejala akan terjadinya tindak kekerasan yang melibatkan peserta didik baik sebagai korban maupun pelaku adalah dengan menerapkan standar operasional yaitu penyelesaian oleh guru kelas terlebih dahulu, kepala sekolah, wali murid, masyarakat, instansi/dinas terkait sesuai dengan tingkat tindak kekerasan yang terjadi. ${ }^{15}$

Adapun upaya penanggulangan sebagaimana disampaikan oleh Siti Fathunnurrohmiyati MIN 1 Jember melakukan upaya sebagai berikut.'

\section{Sekolah}

${ }^{14}$ Siti Fathunnurrohmiyati, Wawancara, 4 Oktober 2017, Ruang Kepala

${ }^{15}$ Ina Ristiyani, Wawancara, 11 Oktober 2017, Ruang Kepala Sekolah 
AL-MUDARRIS:journal of education, Vol. 2. No. 1 April 2019, ISSN: 2620-5831 (print), ISSN: 2620-4355(online)

DOI: 10.32478/al-mudarris.v2i1.223

Pemberian pertolongan, dalam hal ini oleh madrasah, terhadap korban tindakan kekerasan dengan menyediakan prasarana berupa Unit Kesehatan Siswa (UKS). Dalam menanggulangi tindak kekerasan tidak semua kejadian dilaporkan kepada orang tua/ wali murid tetapi melihat tingkat tindak kekerasan yang terjadi. Jika memang terjadi tindak kekerasan maka guru kelas bertanggung jawab untuk melakukan identifikasi fakta dan menyelesaikan kasus yang terjadi di kelasnya. Guru kelas berkoordiansi dengan guru lainnya, kepala sekolah, wali murid dan pihak luar terkait jika kasus yang terjadi di luar kewajaran. ${ }^{16}$

Siti Fathunnurrohmiyati juga menuturkan:

Oleh sebab itu, madrasah selalu menjalin kerjasama dan koordinasi dengan pihak-pihak terkait dalam rangka menjamin hak peserta didik dan memfasilitasi korban untuk mendapatkan hak perlindungan hukum. Madrasah juga melakukan rehabilitasi dan atau fasilitai kepada peserta didik yang mengalami tindak kekerasan. Dan Alhamdulillah selama saya disini belum pernah terjadi tindak kekerasan diluar kewajaran, mengalami luka berat, atau sampai berusuran dengat aparat hukum. ${ }^{17}$

MIN 1 Jember memberikan sanksi terhadap pelaku tindak kekerasan dalam rangka pembinaan. Dalam kaitannya dengan sanksi Siti Fathunnurrohmiyati menyatakan bahwa:

Sanksi yang kami berikan adalah sanksi yang sifatnya mendidik dan menimbulkan efek jera. Sanksi yang kami berikan juga menyesuaikan dengan tingkat kasusnya. Kalua kasus itu masih wajar sebagai anak-anak ya cukup dinasehati, ditegur melalui lisan. Jika merusak barang, sanksinya harus mengganti. Kalau ternyata sanksi sudah

16 Siti Fathunnurrohmiyati, Wawancara, 4 Oktober 2017, Ruang Kepala Sekolah

17 Siti Fathunnurrohmiyati, Wawancara , 4 Oktober 2017, Ruang Kepala Sekolah 
AL-MUDARRIS:journal of education, Vol. 2. No. 1 April 2019, ISSN: 2620-5831 (print), ISSN: 2620-4355(online)

DOI:

diberikan dan siswa tersebut belum jera maka kami akan memanggil orang tuanya untuk membuat surat pernyataan. ${ }^{18}$

\section{Pengembangan Budaya Nirkekerasan di MIN 6 Jember}

Sedangkan MIN 6 Jember dalam melakukan upaya tindakan pencegahan dengan membuat kegiatan-kegiatan yang dapat membangun kedekatan antar warga madrasah. Dengan adanya kedekatan maka diharapkan dapat menumbuhkan saling kepedulian sehingga meminimalisir terjadinya tindak kekerasam. Nawawi selaku kepala MIN 6 Jember mengatakan:

"Untuk mencegah tindak kekerasan disini adalah dengan membangun kedekatan seluruh warga sekolah baik antar murid, murid dengan guru, termasuk juga kedekatan anatar guru. Dengan adanya kedekatan tersebut akan menumbuhkan saling kepedulian sehingga dapat meminimalisir terjadinya tindak kekerasam. Untuk membangun kedekatan itu, kami memiliki beberapa kegiatan rutin, misalnya penyambutan kedatangan siswa, upacara bendera, paguyuban wali murid, anjangsana antar guru dan family gathering." 19

Penguatan hubungan guru dan siswa salah satunya dilakukan dengan program penyambutan kedatangan siswa. Kegiatan ini dilaksanakan setiap pagi di pintu gerbang masuk madrasah. Pada pukul 06.30 atau 30 menit sebelum bel masuk, sebanyak tiga guru bertugas piket untuk menyambut kedatangan siswa. Disamping menyambut siswa, guru juga menanyakan kabar, memotivasi siswa agar bersemangat dalam belajar serta memantau kedisiplinan dan kerapian siswa dalam berpakaian. ${ }^{20}$

Adapun wujud penjaminan madarasah terhadap kenyamanan, keamanan serta keselamatan bagi peserta didik dalam pelaksanaan kegiatan pembelajaran di

18 Siti Fathunnurrohmiyati, Wawancara, 17 November 2014, Ruang Kepala MIN 6 Jember

19 Nawawi, Wawancara, 7 November 2018, Kantor Kepala MIN 6 Jember

${ }^{20}$ Observasi di MIN 6 Jember, 7 November 2017 
lingkungan madrasah maupun kegiatan madrasah di luar satuan pendidikan diwujudkan dengan menyingkirkan benda-benda yang dapat membahayakan peserta didik seperti kayu, batu besar, dan menutup lubang selokan. selama pembelajaran berlangsung pintu gerbang ditutup dan dijaga oleh satpam. Pada saat pulang sekolah satpam bertugas untuk menjaga keselamatan siswa dalam menyeberang jalan dan memastikan bahwa siwa pulang dijemput oleh orang tuanya. Selain itu madrasah juga menyediakan jasa antar jemput bagi siswa yang rumahnya jauh dan tidak dijemput oleh orang tuanya. ${ }^{21}$

Guru kelas bersikap prefentif dalam menyikapi adanya dugaan/gejala akan terjadinya tindak kekerasan yang melibatkan peserta didik baik sebagai korban maupun pelaku dengan cara memanggil siswa yang terlibat melakukan tindak kekerasan. Pemanggilan ini dalam rangka mengidentifikasi permasalahannya serta memberikan konseling sebagai upaya penyelesaian permasalahan. Tindak kekerasan yang sering terjadi di MIN 6 Jember adalah perkelahian dan saling ejek sebagaimana diungkapkan oleh Ashrofah selaku wakil Pembantu Kepala Madrasah Bidang Kesiswaan. ${ }^{22}$

Adapun Nawawi dan Ashrofah menyampaikan upaya penanggulangan diantaranya melakukan upaya pertolongan terhadap korban tindakan kekerasan di satuan pendidikan dengan menyediakan UKS serta bekerjasama dengan puskesmas terdekat. Adapun setiap terjadi tindak kekerasan yang melibatkan peserta didik baik sebagai korban maupun pelaku, madrasah tidak langsung memberitahukan kepada orang tua/wali peserta didik namun diupayakan dulu penyelesaian oleh guru kelas dengan melakukan pendekatan secara personal dengan siswa. Guru kelas bertanggung jawab untuk melakukan identifikasi fakta kejadian tindak kekerasan dalam rangka penanggulangan tindak kekerasan peserta didik. Guru kelas menindaklanjuti

21 Nawawi, Wawancara, 7 November 2018, Kantor Kepala MIN 6

${ }^{22}$ Ashrofah, Wawancara, 14 November 2014, Ruang Guru MIN Jember 
DOI:

kasus kekerasan secara proporsional sesuai dengan tingkat tindak kekerasan yang dilakukan, apakah masih dalam kategori wajar atau diluar kewajaran. Jika tindak kekerasan tersebut dianggap melampaui batas kewajaran maka madrasah akan melakukan pemanggilan terhadap wali murid dalam rangka penyelesaian tindak kekerasan. ${ }^{23}$

Selain itu, MIN 6 Jember memberi jaminan hak peserta didik untuk tetap mendapatkan pendidikan. Hak perlindungan hukum jika terjadi tindak kekerasan yang sampai berimplikasi dengan hukum difasilitasi oleh MIN 6 Jember untuk bisa diperoleh bagi para peserta didik baik sebagai pelaku maupun korban. Pemberian rehabilitasi dan/atau fasilitasi kepada peserta didik yang mengalami tindakan kekerasan juga diberikan oleh MIN 6 Jember dengan cara memberikan perhatian lebih terhadap peserta didik dan pemberian konseling yang mengalami tindak kekerasan. Menurut pernyataan Nawawi dan Ashrofah, Selama ini belum ada kasus tindak kekerasan yang diluar kewajaran yang mengakibatkan luka fisik yang cukup berat/cacat fisik/kematian sampai melaporkan kepada aparat penegak hukum. ${ }^{24}$

MIN 6 Jember memberikan sanksi terhadap pelaku tindak kekerasan dalam rangka pembinaan. Sanksi merupakan cara terakhir setelah proses pencegahan dan penanggulangan tindak kekerasan telah dilakukan tetapi masih belum menimbulkan kesadaran pelaku tindak kekerasaan. dapat Sanksi yang diberikan bertujuan memberikan efek jera sehingga pelaku tindak kekerasan tidak mengulangi kembali perbuatan yang sama di kemudian hari.

Dalam kaitannya dengan sanksi Nawawi menyatakan bahwa:

Sanksi yang diberlakukan di MIN 6 Jember berupa teguran lisan, tulisan, serta sanksi lainnya yang bersifat edukatif.

23 Nawawi dan Ashrofah, Wawancara, 17 November 2014, Ruang Kepala MIN Jember

24 Nawawi dan Ashrofah, Wawancara, 17 November 2014, Ruang Kepala MIN Jember 
Selama ini belum ada sanksi berupa pengurangan hak atau pemberhentian baik kepada siswa, guru dan karyawan. Sanksi yang diberikan madrasah kepada siswa diupayakan bersifat mendidik misal membaca istighfar atau membaca al-Qur'an, menulis surat pernyataan, dilibatkan dalam keikutsertaan membersihkan lingkungan. Min 6 Jember melarang keras guru memberi sanksi yang bersifat fisik seperti memukul, berdiri, berlari push-up dan yang lainnya. $^{25}$

\section{E. PEMBAHASAN}

1. Upaya Pencegahan Tindak Kekerasan di MIN 1 dan MIN 6 Jember

MIN 1 Jember melakukan upaya pencegahan tindak kekerasan menekankan pada komunikasi. Adapun kegiatan kegiatan yang dialakukan adalah upacara bendera, siraman rohani setiap jum'at pagi, rapat bulanan, paguyuban pembentukan group wa wali murid dan seleksi siswa pindahan. Sedangkan MIN 6 Jember melakukan upaya tindakan pencegahan dengan membuat kegiatan-kegiatan yang dapat membangun kedekatan antar warga madrasah seperti penyambutan kedatangan siswa, upacara bendera, paguyuban wali murid, anjangsana antar guru dan family gathering. Dengan adanya kedekatan maka diharapkan dapat menumbuhkan saling kepedulian sehingga meminimalisir terjadinya tindak kekerasam. Sebagaimana disampaikan oleh samani dan Hariyanto yang dikutip ulang oleh Rifqi Amin bahwa pencegahan tindak kekerasan dapat dilakukam dengan internalisasi nilai-nilai anti kekerasan salah satunya adalah nilai kepedulian (compassion). ${ }^{26}$

Baik MIN 1 maupun MIN 6 Jember berupaya mengembangkan pendidikan berbudaya nirkekerasan agar siswa dapat belajar tanpa ada rasa ketakutan, menciptakan suasana yang nyaman dan penuh kekeluargaan. Hal ini sebagaimana dinyatakan oleh Abdur Rachman Assegaf

25 Nawawi dan Ashrofah, Wawancara, 17 November 2014, Ruang Kepala MIN 6 Jember

${ }^{26}$ Amin. 173. 
AL-MUDARRIS:journal of education, Vol. 2. No. 1 April 2019, ISSN: 2620-5831 (print), ISSN: 2620-4355(online)

DOI:

bahwa tujuan pendidikan anti kekerasan adalah untuk menumbuhkan niat belajar, menjalin rasa simpati dan pengertian, menciptakan suasana riang dan saling memiliki, serta nenunjukkan keteladan. ${ }^{27}$

Upacara bendera merupakan kegiatan yang dilakukan baik di MIN 1 Jember maupun MIN 6 Jember. Sebagaimana yang disampaikan Utami Budiyanti bahwa upacara bendera juga sebagai upaya menginternalisasikan nilai-nilai anti kekerasan yaitu nilai ketaatan. Dalam hal ini ketaatan didefinisikan sebagai sikap taat serta patuh, dan tidak melanggar tata tertib yang berlaku. ${ }^{28}$

Paguyuban wali murid juga merupakan kegiatan yang ada di MIN 1 Jember dan MIN 6 Jember. Perbedaan antara paguyuban di MIN 1 Jember diadakan sekali dalam setiap semester sedangkan di MIN 6 Jember diadakan dua kali dalam satu semester. Kegiatan ini bertujuan untuk membangun kedekatan, saling percaya, dan kerjasama antar guru dan karyawanwali murid. Dengan demikian, diharapkan adanya kepercayaan wali murid kepada pihak madrasah. Hal ini sesuai dengan yang dinyatakan oleh $\mathrm{M}$. Noor Rochman Hadjam dan Wahyu Widhiarso bahwa indikator yang mencerminkan budaya anti kekerasan antara lain saling percaya, kerjasama, tenggang rasa, penerimaan terhadap perbedaan (toleransi), dan penghargaan terhadap kelestarian Lingkungan. ${ }^{29}$

MIN 1 Jember dan MIN 6 Jember bersikap prefentif dalam menyikapi adanya dugaan/gejala akan terjadinya tindak kekerasan yang melibatkan peserta didik baik sebagai korban maupun pelaku dengan cara memanggil siswa yang terlibat melakukan tindak kekerasan. Pemanggilan ini dalam rangka mengidentifikasi permasalahannya serta memberikan konseling sebagai

27 Abdur Rachman Assegaf, Pendidikan Tanpa Kekerasan; Tipologi, Kondisi, Kasus, dan Konsep (Yoyakarta: Tiara Wacana, 2014). 78.

28 Utami Budiyanti, 'Pendidikan Anti Kekerasan dalam Buku Ajar Pendidikan Agam Islam (Telaah Atas Buku Ajar PAI SMA Kelas X, XI, XII Terbitan Erlangga Tahun 2007)' (UIN Suanan Kali Jaga, 2014).

${ }^{29}$ M. Noor Rocman Hadjam. 15. 
AL-MUDARRIS:journal of education, Vol. 2. No. 1 April 2019, ISSN: 2620-5831 (print), ISSN: 2620-4355(online)

DOI: 10.32478/al-mudarris.v2i1.223

upaya penyelesaian permasalahan. Tindak kekerasan yang sering terjadi di MIN 1 Jember dan MIN 6 Jember adalah perkelahian dan saling ejek. Dari pengakuan beberapa siswa juga diperoleh informasi ada salah seorang guru sering membentak, memarahi siswa dan tidak jarang pula untuk memukul dan mencubit meskipun tidak sampai menimbulkan bekas apalagi luka.

Menurut Nurul Ikhsan Saleh tindak kekerasan tersebut tersebut termasuk dalam bentuk tindak kekerasan fisik dan psikis. Tindak kekerasan fisik adalah jenis kekerasan yang tampak oleh mata misal memar atau berdarah akibat perkelahian. Sedangkan kekerasan psikis adalah jenis kekerasan yang akibatnya tidak tampak mata contoh tindakan mengolok-olok (bully). ${ }^{30}$ Lebih lanjut Les Parsons menjelaskan bahwa terdapat 3 jenis kekerasan yakni: (1) kekerasan lisan atau tertulis, yakni kekerasan melalui penggunaan stereotip-stereotip dan penanaman yag bermuatan rasis, seksis, kultur, sosio-ekonomi, dan ketidaksempurnaan fisik / mental, dan homofobik; (2) Kekerasan fisik, seperti perbuatan mendorong, mencubit, menarik rambut atau telinga, memukul dengan penggaris, atau melemparkan sesuatu; (3) Kekerasan psikologis seperti berteriak, menyobek hasil kerja, berbicara dengan sarkasme, mengadu domba siswa, dan mengancam; (4) kekerasan yang berkaitan dengan profesionalisme seperti penilaian yang tidak adil, menerapkan hukuman dengan pilih-pilih, menggunakan cara-cara pendisiplinan yang tidak pantas, menetapkan kriteria ketuntasan mininimal (KKM) yang tinggi, memberikan data yang tidak valid tentang perilaku siswa, dan mengahalangi siswa untuk memperoleh kesempatan balajar. ${ }^{31}$

Dari pemaparan data di atas, dapat peneliti simpulkan bahwa dalam upaya pencegahan MIN 1 Jember

${ }^{30}$ Nurul Ikhsan Saleh, Peace Education: Kajian Sejarah, Konsep, dan Relevansinya dengan Pendidikan Agama Islam (Yogyakarta: Ar-Ruzz Media, 2012). 47.

31 Les Parsons, Teacher Bullied Student. Terjemahan G. Warong. (Jakarta: Grasindo). 71 
AL-MUDARRIS:journal of education, Vol. 2. No. 1 April 2019, ISSN: 2620-5831 (print), ISSN: 2620-4355(online)

DOI:

dan MIN 6 Jember memliki cara yang berbeda. MIN 1 Jember lebih mengedepankan komunikasi sedangkan MIN 6 Jember lebih menonjolkan kedekatan atau keakaraban.

\section{Upaya Penanggulangan Tindak Kekerasan di MIN 1 dan MIN 6 Jember}

MIN 1 Jember dan MIN 6 Jember dalam mengimplementasikan upaya penanggulangan tindak kekerasan memiliki persamaan diantaranya dengan menyediakan UKS dalam upaya memberikan pertolongan terhadap korban tindakan kekerasan di satuan pendidikan serta bekerjasama dengan puskesmas terdekat. Madrasah tidak langsung memberitahukan kepada orang tua/wali peserta didik setiap terjadi tindak kekerasan yang melibatkan peserta didik baik sebagai korban maupun pelaku, namun diupayakan dulu penyelesaian oleh guru kelas dengan melakukan pendekatan secara personal dengan siswa. Guru kelas bertanggung jawab untuk melakukan identifikasi fakta kejadian tindak kekerasan dalam rangka untuk menanggulangi tindak kekerasan oleh dan atau terhadap peserta didik. Guru kelas menindak lanjuti kasus kekerasan secara proporsional sesuai dengan tingkat tindak kekerasan yang dilakukan, apakah masih dalam kategori wajar atau diluar kewajaran. Jika tindak kekerasan tersebut dianggap melampaui batas kewajaran maka madrasah akan melakukan pemanggilan terhadap wali murid dalam rangka penyelesaian tindak kekerasan.

Berkaitan dengan apa yang telah dilakukan MIN 1 dan MIN 6 Jember dalam menanggulangi tindak kekerasan, dapat diketahui bahwa MIN 1 dan MIN 6 Jember menyikapinya secara proporsional. Hal ini sesuai dengan apa yang telah disampaikan oleh al-Ghazali sebagaiman dikutip oleh Assegaf bahwa guru harus menaruh rasa kasih sayang kepada siswa sama seperti memperlakukan anak sendiri. Guru juga hendaknya mampu mencegah anak dari akhlak yang tercela dengan cara yang baik. Selain itu guru harus memperhatikan tingkat akal pikiran anak ketika 
AL-MUDARRIS:journal of education, Vol. 2. No. 1 April 2019, ISSN: 2620-5831 (print), ISSN: 2620-4355(online)

DOI: 10.32478/al-mudarris.v2i1.223

berbicara dengan siswa. ${ }^{32}$ dengan cara tersebut, diharapkan nasihat yang diberikan guru dapat diterima oleh siswa sehingga tindak kekerasan serupa tidak akan terjadi lagi.

Selain itu, MIN 1 dan MIN 6 Jember memberi jaminan hak peserta didik untuk tetap mendapatkan pendidikan. Kedua madrasah tersebut juga memfasilitasi peserta didik, baik sebagai korban maupun pelaku, untuk mendapatkan hak perlindungan hukum jika terjadi tindak kekerasan yang sampai berimplikasi dengan hukum. Selain itu kedua madrasah juga memberikan rehabilitasi dan/atau fasilitasi kepada peserta didik yang mengalami tindakan kekerasan dengan memberikan perhatian lebih terhadap peserta didik dan pemberian konseling yang mengalami tindak kekerasan.

Dari pernyataan di atas dapat disimpulkan bahwa MIN 1 dan MIN 6 selama ini lebih mengedepankan langkah-langkah prefentif dalam rangka mencegah terjadinya tindak kekerasan. Meskipun demikian upaya penanggulangan tindak kekerasan secara prosedural sudah direncanakan. Meskipun, dalam realisasinya hal tersebut belum pernah dilakukan karena belum pernah terjadi tindak kekerasan yang diluar kewajaran yang berimbas terhadap proses hukum.

\section{Sanksi bagi Pelaku Tindak Kekerasan di MIN 6 Jember}

MIN 1 dan MIN 6 Jember memberikan sanksi terhadap pelaku tindak kekerasan dalam rangka pembinaan. Sanksi merupakan cara terakhir setelah proses pencegahan dan penanggulangan tindak kekerasan telah dilakukan tetapi masih belum menimbulkan kesadaran pelaku tindak kekerasaan. Sanksi yang diberikan bertujuan memberikan efek jera sehingga pelaku tindak kekerasan tidak melakukan tindakan serupa di kemudian hari. Hal ini senada dengan apa yang diungkapkan Al-Maghribi bahwa ketika penggunaan berbagai sarana atau metode kurang efektif dalam mencapai tujuan dan bahkan mengalami kegagalan maka metode pemberian sanksi merupakan cara terakhir

${ }^{32}$ Assegaf. 78 
AL-MUDARRIS:journal of education, Vol. 2. No. 1 April 2019, ISSN: 2620-5831 (print), ISSN: 2620-4355(online)

DOI:

yang bisa dilakukan. Saat itulah sanksi boleh diberikan. Pemilihan waktu haruslah tepat ketika menjatuhkan hukuman dan harus disesuaikan pula dengan tingkat kesalahan yang dilakukan. ${ }^{33}$

Menurut Yulianto pelanggaran yang dilakukan peserta yang tidak dapat ditoleransi dan dicegah kecuali dengan memukulnya, maka diperbolehkan dengan memukul asalkan dalam konteks mendidik. ${ }^{34}$ Berbeda dengan Pudji Susilowati yang menyatakan kekerasan pada siswa tidak bisa dibenarkan karena seringkali kekerasan dijadikan dalih untuk mendidik siswa. Oleh karena, lembaga pendidikan harus dapat menjadi tempat nyaman, aman, dan tenteram secara fisik dan psikis bagi siswa dan seluruh komunitas yang ada di dalamnya. ${ }^{35}$ Setiap pendidik harus memahami tentang batasan-batasan sebuah tindakan atau sanksi yang termasuk kekerasan. Kekerasan tidak hanya fisik tetapi juga dapat berupa kekerasan verbal atau tertulis dan juga kekerasan psikologis. Sebagai seorang pengajar, seorang guru dituntut untuk bisa bekerja secara cerdas dan kreatif dalam menyampaikan materi atau pengetahuan kepada siswa, dan seorang guru juga dituntut untuk menanamkan nilai moral, kedisiplinan, sopan santun, dan menjaga ketertiban serta peraturan disekolah. Penggunaan bahasa sangatlah penting untuk diperhatikan bagi seorang guru dalam mendidik. Bahasa yang sopan, bukan bahasa sarkasme, haruslah digunakan oleh seorang guru baik itu dalam menegur maupun memberikan nasihat. Seorang guru juga harus bisa menumbuhkan kesadaran kepada anak didiknya tentang budaya nirkekerasan atau bahaya

33 Al-Maghribi bin as-Said Al-Maghribi, Begini Seharusnya Mendidik Anak: Panduan Mendidik Anak dari Masa Kandungan Hingga Dewasa (Jakarta: Darul Haq, 2004). 387.

${ }^{34}$ Yulianto, 'Konsep Pendidikan Anak Dalam Perspektif Ibnu Hajar AlHaitami (Ragam Eksplorasi Kitab Tahrīru Al-Maqōl F̄̄ Adābi Wa Ahkāmi Wa Fawā'idu Yahtāju Ilaihā Mu'addibū Al-Atfāl)', $1.1 \quad$ (2018) <http://ejournal.staima-alhikam.ac.id/index.php/al-mudarris/article/view/98>.

35 Tri Lestari Utami, 'Kekerasan Pada Siswa di Sekolah', 2013 <http://jurnalilmiahtp2013.blogspot.com/2013/12/kekerasan-dalam-duniapendidikan.html> [accessed 8 November 2018]. 
AL-MUDARRIS:journal of education, Vol. 2. No. 1 April 2019, ISSN: 2620-5831 (print), ISSN: 2620-4355(online)

DOI: 10.32478/al-mudarris.v2i1.223

kekerasan serta akibat yang akan ditimbulkan. Dan juga tentang pemberlakuan sanksi yang seharusnya diberlakukan ketika terjadi pelanggaran tata tertib, jika sanksi itu tidak ditegakkan secara konsisten dikhawatirkan kasus kekerasan akan semakin bertambah banyak. Dengan pemberlakuan sanksi yang tegas akan meminimalisir jumlah tindak kasus kekerasan. ${ }^{36}$

Dalam pendidikan, sanksi tidak sepenuhnya diperlukan, sebagaimana yang dinyatakan oleh Abdullah Nasih Ulwan bahwa untuk membuat siswa jera, pendidik harus bersikap bijaksana dalam memilih dan menggunakan metode yang paling sesuai. ${ }^{37}$ Tidak semua anak didik perlu diberikan hukuman, ada yang cukup dengan pemberian nasihat atau bahkan teladan saja. Namun, guru juga harus menyadari bahwa tidak semua siswa seperti itu, ada beberapa diantara siswa yang perlu diberikan sanksi sebagai efek jera agar mereka sadar atas kesalahan yang telah dilakukan. ${ }^{38}$

\section{F. KESIMPULAN}

Hasil penelitian ini menunjukkan bahwa MIN 1 dan MIN 6 Jember telah mengembangkan pendidikan berbudaya nirkekerasan dengan melakukan upaya pencegahan dan penanggulangan tindak kekerarasan serta memberi sanksi terhadap pelaku tindak kekerasan. MIN 1 Jember telah melakukan upaya tindakan pencegahan dengan membuat kegiatan-kegiatan yang dapat membangun komunikasi antar warga madrasah sedangkan MIN 6 Jember telah melakukan upaya tindakan pencegahan dengan membuat kegiatan-kegiatan yang dapat membangun kedekatan antar warga madrasah. Dalam upaya penanggulangan tindak kekerasan, MIN 1 dan MIN 6

36 arofah Septalinda M, 'Kekerasan dalam Dunia Pendidikan', 2013 $<$ https://arofaheducation.wordpress.com/2013/07/03/kekerasan-dalam-duniapendidikan/> [accessed 15 November 2018].

37 Abdullah Nasih Ulwan, Pendidikan Anak dalam Islam, terj. by Jamaludin Miri (Jakarta: Insan Kamil, 1994). 333.

${ }^{38}$ Muhammad Quthb, Sistem Pendidikan Islam, terj. by Salman Harun (Bandung: al -Ma'arif, 1993). 34 
DOI:

Jember menindaklanjuti kasus kekerasan yang terjadi secara proporsional dan sesuai dengan standar prosedur yang telah ditentukan. Dalam hal pemberian sanksi terhadap pelaku tindak kekerasan MIN 1 dan MIN 6 Jember memberikan sanksi berupa teguran lisan, tulisan, serta sanksi lainnya yang bersifat mendidik.

\section{DAFTAR PUSTAKA}

Abu-Nimer, Mohammed, Nirkekerasan Dan Bina Damai Dalam Islam: Teori Dan Praktik (Jakarta: Pustaka Alvabet, 2010)

Al-Maghribi, Al-Maghribi bin as-Said, Begini Seharusnya Mendidik Anak: Panduan Mendidik Anak Dari Masa Kandungan Hingga Dewasa (Jakarta: Darul Haq, 2004)

Amin, A. Rifqi, Pengembangan Pendidikan Agama Islam;

Reinterpretasi Berbasis Interdisipliner (Yogyakarta:

LkiS Pelangi Aksara, 2015)

Assegaf, Abdur Rachman, Pendidikan Tanpa Kekerasan;

Tipologi, Kondisi, Kasus, Dan Konsep (Yoyakarta:

Tiara Wacana, 2014)

Budiyanti, Utami, 'Pendidikan Anti Kekerasan Dalam

Buku Ajra Pendidikan Agam Islam (Telaah Atas

Buku Ajar PAI SMA Kelas X, XI, XII Terbitan

Erlangga Tahun 2007)' (UIN Suanan Kali Jaga, 2014)

'Http://Kbbi-Offline.Googlecode.Com'

Kebudayaan, Departemen Pendidikan dan, Pendidikan

Dan Kebudayaan, Kamus Besar Bahasa Indonesia (Jakarta: Balai pustaka, 1997)

Latif, Abdul, Pendidikan Berbasis Nilai Kemasyarakatan (Bandung: Refika Aditama, 2005)

M. Noor Rocman Hadjam, Wahyu Widhiarso, Damai Anti Kekerasan (Peace and Anti Violence) (Dirjen Pendidikan Menengah Umum, 2003)

M, AROFAH SEPTALINDA, 'KEKERASAN DALAM DUNIA PENDIDIKAN', 2013 $<$ https://arofaheducation.wordpress.com/2013/07/03/k ekerasan-dalam-dunia-pendidikan/> [accessed 15 
AL-MUDARRIS:journal of education, Vol. 2. No. 1 April 2019, ISSN: 2620-5831 (print), ISSN: 2620-4355(online)

DOI: 10.32478/al-mudarris.v2i1.223

November 2018]

Medcom.id, 'KPAI : 84 \% Siswa Pernah Alami Kekerasan

Di Sekolah', Www.Medcom.Id, 2018

Parsons, Les, Teacher Bullied Student. Terjemahan $G$.

Warong. (Jakarta: Grasindo)

Paulo Fraire, Ivan Illich, Erich Fromm, Pendekatan

Humanisme Dan Pendidikan Pembebasan, ed. by

Omi Intan Naomi (Yogyakarta: Pustaka pelajar, 1994)

Permendikbud Nomor 82 Tahun 2015 Tentang

Pencegahan Dan Penanggulangan Tindak Kekerasan

Di Lingkungan Satuan Pendidikan

Quthb, Muhammad, Sistem Pendidikan Islam, Terj. by

Salman Harun (Bandung: al -Ma'arif, 1993)

Saleh, Nurul Ikhsan, Peace Education: Kajian Sejarah,

Konsep, Dan Relevansinya Dengan Pendidikan

Agama Islam (Yogyakarta: Ar-Ruzz Media, 2012)

Subono, Nur Iman, Erich Fromm: Psikologi Sosial

Materialis Yang Humanis (Jakarta: Kepik Ungu, 2010)

Suppriyadi, Yohanes, 'Pendidikan Anti Kekerasan; Paradigma Baru Dunia Pendidikan Menuju Kehidupan Yang Harmonis Di Masa Depan', Yohanessupriyadi.Blogspot.Co.Id, 2008

Tri Lestari Utami, 'Kekerasan Pada Siswa Di Sekolah', 2013

<http://jurnalilmiahtp2013.blogspot.com/2013/12/kek erasan-dalam-dunia-pendidikan.html> [accessed 8 November 2018]

Ulwan, Abdullah Nasih, Pendidikan Anak Dalam Islam, ed. by Jamaludin Miri (Jakarta: Insan Kamil, 1994)

Yulianto, 'Konsep Pendidikan Anak Dalam Perspektif Ibnu Hajar Al-Haitami (Ragam Eksplorasi Kitab Tahrīru Al-Maqōl F̄̄ Adābi Wa Ahkāmi Wa Fawā'idu Yahtāju Ilaihā Mu`addibū Al-Ațfāl)', 1 (2018) $<$ http://e-journal.staima-alhikam.ac.id/index.php/almudarris/article/view/98> 